\title{
The Effect of Teacher Feedback on the Simple Past Tense Acquisition in Senior High School Students' English Writing
}

\author{
Qin Zhong ${ }^{1, *}$, Minwei Yan $^{1} \&$ Fangfang Zou ${ }^{1}$ \\ ${ }^{1}$ School of Foreign Language, Jiangxi Normal University, Jiangxi Province, China \\ *Correspondence: School of Foreign Language, Jiangxi Normal University, Ziyang Road No.99, Nanchang City, \\ Jiangxi Province, China. E-mail: 1830966548@qq.com \\ (This research belongs to graduates' innovation fund project of Jiangxi Normal University supported by Jiangxi \\ Education Department)
}

Received: April 14, 2019

Accepted: May 27, 2019 Online Published: June 5, 2019

doi:10.5430/wje.v9n3p30

URL: https://doi.org/10.5430/wje.v9n3p30

\begin{abstract}
Teacher feedback is an essential part which can not be overlooked in English writing teaching. Whether teacher feedback is effective and which type of feedback is more effective in improving learners' writing proficiency have attracted more and more researchers' attention. Direct feedback is the feedback that teachers correct students' errors directly under the form or the right using habit of target language. Indirect feedback is the feedback that teachers only mark out or point out students' errors but not correct errors. This study explores the effects of two different kinds of feedback (direct feedback and indirect feedback) on the acquisition of English simple past tense in high school students' writing. And it attempts to answer the following three questions: 1) Do teachers' direct and indirect feedback in English writing influence senior high school students' acquisition of simple past tense? 2) If so, which kind of feedback (direct or indirect feedback) has the greater influence on improving students' acquisition of simple past tense in English writing? 3) What perceptions do students have towards teachers' direct and indirect feedback in English writing?

The result showed that the two kinds of feedback have an influence on the acquisition of the target structure, however, there is no significant difference between direct and indirect feedback group, which states that indirect feedback class was not better than direct feedback class.
\end{abstract}

Keywords: direct feedback, indirect feedback, English writing in high school, English simple past tense

\section{Introduction}

At present, many students show a negative attitude towards English writing and have difficulty in writing a composition. Usually, students just use some words to write down several simple sentences relevant to the given message. Their writing ability have to get improved. It is not strange to see students write a short writing which includes lots of mistakes. What causes this kind of phenomenon on earth?

One of the main reason accounted for this may be the teaching approach. In Chinese writing teaching field, product writing approach has dominated a role for a long time. Product writing approach mainly emphasizes the words and grammar, as a result, it overlooks the content and logic. As time went by, many researchers note the disadvantages of product writing and shift the focus to the process writing. The process writing approach is students-centered, which is in line with the most popular teaching idea of letting learners to be the center of the class. Teachers need to realize the importance of students' role. When students become the center of the role, they will learn actively and autonomously. At that point, students write actively, but inevitably they would make some mistakes. What should teachers do to help students improve? That is to give feedback when students make writing errors.

The effect of written corrective feedback has been studied by many researchers, but which one is the most effective corrective feedback hasn't been proved yet. Some researchers argued that direct corrective feedback was effective, but some others stated that it was indirect corrective feedback that was more effective. Researchers haven't reached an agreement which feedback is more effective. However, written feedback is necessary and important in teaching 
writing. So it needs more research to find out effective way to improve students' writing ability and level.

This study investigates the influence of direct and indirect feedback on the acquisition of simple past tense in senior high school students' writing, and discusses the effects of direct and indirect feedback. Which one has more positive influence on learners' acquisition of simple past tense is discussed in the present study. And students' attitude and preference to teacher feedback is investigated in this study.

\section{Literature Review}

\subsection{Definition of Feedback}

Feedback was one of the essential factors in the process of writing teaching (Keh, 1999). Writings or articles can be polished and improved via the feedback information and feedback has a great influence on essay writing.

Carson (1979) defined feedback in writing teaching as the information that students receive from authority to improve and revise their responses for instructions or guidance and lead them to acquire the target in a more effective way. Lalande (1982) thought feedback as any procedure used to inform a learner where an instructional response is right or wrong.

Then, Keh (1999) explained feedback more specifically, he thought the resource of feedback is reader's input, and it could provide revision based on reader's effective understanding. In other words, feedback has an influence on learners and is helpful to improve learners' learning.

Ellis (1994) regarded feedback as a term for information learners receive which can be used to receive their interlanguage. Then, Ur (1996) thought that feedback is the returned information from one certain assignment whose aim is to improve and increase the students' grades and performance. Nevertheless, in Kulhavy's (1997) opinion, he defined feedback as a process from which we judge the learners' reactions to teaching.

According to the research of Zhang Xuemei and Dai Weidong (2001), feedback is composed mainly of two components: evaluation and correction. Test scores and the teachers' brief comments such as "good" and "right" are different forms of evaluation, while correction refers to some more detailed guidance which the teachers give to the performance of the students.

As what's mentioned above, different people have different understanding of feedback, so the definitions about feedback are diverse. It is acknowledged that feedback is an essential issue in language teaching and learning. Definition of feedback in this study is similar to Carson's opinion. This paper mainly focuses on the teachers' direct and indirect feedback on senior high school students' English writing. Teachers often viewed as the authority give feedback to students' writing which aims to improve students' acquisition of simple past tense. With teachers' instruction and guidance, students achieve the target in a more effective and efficient way.

\subsection{Teacher Feedback}

Teacher feedback plays an important role in L2 writing. Not only oral feedback but also written feedback from teachers can be the response penetrating into students' individual situation in details. In this way, it will be beneficial for students to discover their shortcomings and to improve. Feedback from teachers can focus on the organization or content as for the aspect of discourse; It also can be concentrated on the vocabulary, grammar, or pronunciation as to the language form. Teacher feedback has its own advantages: on one hand, students can discover their weakness with the help of teacher feedback; On the other hand, teachers can acquire students' learning situation which in turn will be beneficial to the teaching and learning. Ferris and Roberts (2001) told feedback into direct feedback and indirect feedback. Those two types of teacher feedback can be distinguished based on whether the teacher provides the correct form for students.

\subsubsection{Direct Teacher Feedback}

Ferris (2001) stated that direct feedback is provided when the teacher writes the correct form onto the student's paper. If the student revises the text, he or she only needs to transcribe the correction in the final version. Direct feedback is defined as giving correct language form or structure on or beside the language errors (Bitchener, Young \& Cameron, 2005), including eliding the redundant words, expressions and phrases; adding missing words, expressions and phrases; and providing correct forms or structures. Other forms about direct feedback include written meta language comments (providing grammar rules or examples in the end of the writing as reference for students to correct errors) and oral meta language comments (having a class to show students rules or examples and then students practice and discuss; teacher-student communication or teachers communicating with students group would be followed). However, teachers' direct feedback has defects: It will reduce students' attention to feedback from teachers in the 
long term; Students get the corrections without their own thinking. And teachers may make mistakes sometimes and have their own subjective opinion imposed on students, which will mislead students and affect students' personal development.

\subsubsection{Indirect Feedback}

Indirect feedback occurs when the teacher indicates in some way, such as underlining, circling, highlighting to note the errors but without correction, letting the writer solve it by himself or herself (Ferris \& Roberts, 2001). Indirect feedback means teachers only give some hints on students' mistakes but would not provide students with clear and correct answer. Students have to correct on their own. There are four forms of indirect feedback: underlining errors; circling errors; labeling the number of errors on the space of margin; and using codes to mark out errors and error types ( Robb, Ross, \& Shortreed, 1986). Compared with direct feedback, indirect feedback has many merits: Teachers just point out the inappropriateness but would not give the correct answers. So students will have space and chance to think autonomously and to make corrections through their own efforts. In a way, students' sense of responsibility and achievements will foster. Meanwhile, students will develop good learning habit and cultivate effective learning strategies. Insufficiency of indirect feedback can not be overlooked: Underachiever students are unable to correct their mistakes.

\subsection{Studies on Teacher Feedback}

The focus on effectiveness of various teacher feedback was the different function of direct feedback and indirect feedback on improving students' language accuracy. Some researches that identify the characteristics of effective feedback and feedback that is not effective or has a negative effect on learning (e.g. Hattie, 2012; Wiggins, 2012).

Some scholars tended to think that indirect feedback can provide some useful information for students. Elham Eslami (2014) explored the effects of direct and indirect corrective feedback techniques on EFL students' writing and found that the indirect feedback group outperformed the direct feedback group. Frear \& Chiu( 2015) examined the effectiveness of focused and unfocused written corrective feedback (WCF) on the accuracy of weak verbs and the total accuracy of all structures in new pieces of writing. The outcome proved that the indirect WCF likely served as a signal for the learners to push their output in their overall accuracy when writing new pieces of writing. Jamalinesari, Rahimi, Gowhary and Azizifar studied the effects of teacher-written direct vs. indirect feedback on students' writing, and the data revealed that the class with indirect feedback improved better compared to the class with direct feedback.

Scholars approving direct feedback indicated that both teachers and students preferred direct feedback. Ferris (2002) made a conclusion that direct feedback can result in more error corrections among students than indirect feedback. However, after a term, he concluded that students receiving indirect feedback had lower frequency to make errors and the decline was more obvious than direct feedback. Researchers in favor of direct feedback considered direct feedback could avoid the situation when students couldn't understand and remember the meaning of coding used by teachers. Ferris and Roberts (2001) insisted that direct feedback has overt advantages for students with lower English level. Chandler (2003) further explained that students receiving indirect feedback were uncertain about their error correction. Thus, students would be prevented from knowing the correct answers in time, which would counteract the advantage of cognitive effort in indirect feedback.

\subsection{Summary}

The previous studies gave me a lot of inspiration. After learning those studies, I linked direct and indirect feedback with senior high school students' acquisition of simple past tense in English writing. Simple past tense is widely used in narration while students are easily to make mistakes. What's worse, teachers often ignores this point. Therefore, this paper will fill the gap in literature by investigating senior high school students attitudes to teacher feedback, teacher feedback's implementation of the use of simple past tense in English writing, as well as making a comparison between the direct and indirect feedback on the use of simple past tense.

\section{Methodology}

This research carried out in a senior high school and the teacher has been teaching for more than 5 years. Teacher direct feedback and indirect feedback would be applied in students' writing. Four writing tasks were assigned in the research. Also, a pretest and posttest were applied.

\subsection{Research Questions}

According to the research objectives mentioned before, three research questions will be presented below: 
(1) Do teachers' direct and indirect feedback in English writing influence senior high school students' acquisition of simple past tense?

(2) If so, which kind of feedback (direct or indirect feedback) has the greater influence on improving students' acquisition of simple past tense in English writing?

(3) What perceptions do students have towards teachers' direct and indirect feedback in English writing?

\subsection{Research Participants}

There are 97 students in the two classes, however, the number of students that participated in the four writing tasks were not the same. The teacher is the same of the two classes. Only 63 students took part in the four writing tasks. Class one has 31 students and worked as the direct group. The teacher pointed out and corrected mistakes directly based on students' errors without any change on their content of the original piece. Class two has 32 students and worked as the indirect group. The teacher pointed out and underlined the mistakes directly but did not correct errors.

\subsection{Research Method}

A pretest of sentence correction with 20 items would be used in the first week to test students' present level and whether exist difference between the two classes. Next week students were asked to finish writing task one and all the writings were collected. The third week students in the indirect feedback group were required to correct errors according to teachers' feedback. Another three writings were assigned as the same. The last week, students had to finish the posttest which consists of sentence correction with 20 items. Then the questionnaire was given to students.

The pretest, four writing tasks and posttest were analyzed by the teacher and the author. The grades were the averages. The four writing tasks are narrative writing. And the simple past tense is the target structure. All the data were analyzed by the Spss.17.0.

\section{Results and Discussion}

\subsection{Results}

The first research question is whether direct feedback or indirect feedback has an influence on the simple past tense acquisition in senior high school students' English writing. As statistics showed, the direct feedback evidently affected the accuracy of the simple past tense from pretest to the posttest (sig. $=.000<.001$ ). It is the same with the indirect feedback (sig. $=.000<.01$ ). So the data revealed the results that both direct feedback and indirect feedback made great progress in acquisition of simple past tense in the posttest. Additionally, the mean score of the posttest in the direct feedback class and indirect feedback was much higher than that of the pretest. It is clear that there existed an increase in the direct feedback class from pretest (Mean=8.03, $\mathrm{S}=3.886$ ) to posttest (Mean=14.10, $\mathrm{S}=3.155$ ). It is the same with the Indirect feedback class, with an increase from pretest (Mean=9.13, S=3.635) to posttest (Mean=13.28, S=3.485). Nevertheless, the mean score of the DF class increased higher than the IF class. The mean score of the DF class and the IF class both increased. So it showed that the students in the direct and indirect feedback class improved their accuracy of simple past tense.

The second research question is which kind of feedback (direct or indirect) has better influence on the acquisition of simple past tense in English writing. With the purpose of pointing out which kind of feedback (direct or indirect) has greater effect on the acquisition of simple past tense on students' writing, the Independent Samples Test was used. As results shown, the Sig. Value of writing task1, task2 and task 4 was respectively $.369, .145, .636$, which were higher than 0.05. It showed that there was no significant difference between the influence of direct feedback and indirect feedback on the acquisition of simple past tense, although the two kinds of feedback influenced the acquisition of simple past tense in students' writing.

The Independent Sample Test showed there was no significant difference between the influence of direct feedback and indirect feedback on the acquisition of simple past tense. Comparing the mean score of writing task 1 and writing task 4 in DF class, the mean score increased from $13.629(\mathrm{~S}=4.5276)$ to $16.516(\mathrm{~S}=3.0862)$. The mean score of writing task 1 and writing task 4 in IF class increased from 12.406( $\mathrm{S}=5.3074)$ to $16.531(\mathrm{~S}=3.2526)$. This showed that students' writing score increased and their writing has improved although there was no significant difference between the influence of direct feedback and indirect feedback on the acquisition of simple past tense. The different themes of writing task 1 and writing task 2 may be the reason for this outcome. The Independent Sample Test also was used to examine writing task 1 and writing task 4 of the two classes. The Sig. value was .000 in both DF class $(\mathrm{T}=-20.909$, Sig. $=.000)$ and IF class $(\mathrm{T}=-41.686, \mathrm{Sig} .=.000)$. This result showed that direct feedback and indirect feedback had an influence on students' English writing after the writing practice. 
The sentence and word errors of simple past tense in the four writing tasks were figured out. The percentage of simple past tense errors in the indirect feedback class was lower than that of direct feedback class from writing task two to writing task four. As the statistics showed, the errors of simple past tense were not stable. However, the total error in direct feedback class was 444, which was more than that of the indirect feedback class (384). Meanwhile, the error of regular simple past tense was much fewer than the error of irregular simple past tense in both direct feedback and indirect feedback class. This may improve that indirect feedback has a better influence on the influence of simple past tense's form.

The third research question was about students' attitudes, preferences and expectations of teacher feedback. As the results showed in the questionnaire, students in direct and indirect feedback class expected and valued teacher feedback. Also, most students preferred direct feedback given by the teacher.

\subsection{Discussion}

Results showed that direct feedback and indirect feedback has an influence on the simple past tense acquisition in senior high school students' English writing. The results of this study were in line with Ellis' (1997) finding. He discovered that direct feedback could influence language accuracy. And the influence was positive, which is beneficial for students to get improvement. In other words, feedback is effective in students' language acquisition; feedback can make students pay more attention to their language accuracy. Also, Ferris (1997) stated that teacher feedback has a positive effect on language accuracy in students' writing. The results of this study were on the contrary to some studies of several researchers (e.g. Purves, 1984); Kepner, 1991; Fazio, 2001) who have found that written feedback has no positive effect on improving students' L2 language accuracy. Purves (1984) considered that suggestions from teachers would restrict students' thinking and had no evident effects on students. Kepner (1991) found there was no significant difference in the grammatical accuracy between the feedback group and no feedback group. Therefore, he concluded that feedback that focuses on grammar was not effective in improving language accuracy. Fazio (2001) carried out a study about the effects of feedback on writing accuracy and feedback in this study exhibited harmful effect on learning. In the present study, both the performance of the direct feedback class and the indirect feedback class in the posttest were outperformed than that of the pretest. It revealed that no matter the direct feedback or indirect feedback group was effective in the acquisition of simple past tense. The accuracy of simple past tense was improved.

The Sig. Value of writing task1, task2 and task 4 was respectively $.369, .145, .636$, which were higher than 0.05 ., which were higher than 0.05 . It showed that there was no significant difference between the influence of direct feedback and indirect feedback on the acquisition of simple past tense in English writing. Truscott's findings can account for this result. Truscott $(1996,1999)$ claimed that feedback may enable students to correct errors in the revision, but in a new piece of writing it had no effect on grammatical accuracy (ie. it didn't lead to acquisition), because feedback only led to L2 explicit knowledge, not implicit knowledge. Students' writing which focused more on implicit knowledge, can not be acquired. Converting corrective feedback into long term acquisition must be achieved internally by the learners themselves, in accordance with their particular learning goals. Additionally, Kepner (1991) concluded that feedback focuses on grammar was not effective in improving language accuracy. The findings listed above were concurrent with the result in this paper.

The sentence and word errors of simple past tense may improve that indirect feedback has a better influence on the influence of simple past tense's form. Some studies (Ferris \& Hedgcock, 2005; Lalande, 1982; Sheen, 2007) showed advantage of indirect feedback over direct feedback. For example, Corder (1967) also argued that direct feedback which just gave the correct form restrained students' thinking ability and it may not be the most effective correction form. The most instructive way for students is trying to discover the right form on their own. Ferris \& Hedgcock (2005) reported that indirect feedback (underlining) appears to have a more positive effect on long term accuracy improvement than direct feedback. Eslami (2014) explored the effects of direct and indirect corrective feedback techniques on EFL students' writing and found that the indirect feedback group outperformed the direct feedback group. Frear and Chiu (2015) proved that the indirect WCF likely served as a signal for the learners to push their output in their overall accuracy when writing new pieces of writing. Ali J, Farahnaz R., Hsbib G., \& Akbar A. (2015) studied the effects of teacher-written direct vs. indirect feedback on students' writing, and the data revealed that the class with indirect feedback improved better compared to the class with direct feedback. All these studies approved that indirect feedback has an advantage over direct feedback.

Most previous studies of learners' views toward teacher feedback (e.g. Ferris, 2001; Hedgcock \& Lefkowitz, 1994) have reported that L2 learners want, expect, and value teacher feedback on their errors. The result in this research is similar to previous studies. However, students preferred direct feedback and expected their teacher to underline and 
correct all their errors for them. The result is similar to the survey conducted by Lalande (1982). Most students admitted that they took teacher feedback seriously and correct by themselves first, then ask for teacher's help if they have problems. Cohen (1987) reported that most of the learners claimed that they read their returned writings carefully and paid attention to teachers' comments. The result that students value teacher feedback is the same with Cohen's idea. As for the expectations of teacher feedback's content, feedback on grammar points ranked the first. This result is similar to Leki's. Leki (1991) found that learners would like to get general comments on grammar instead of content. However, Hedgcock and Lefkowitz (1994) reported a more complicated result. English as second language learners would pay attention to feedback on content, while EFL learners would focus on form. The reason may be due to the fact that EFL learners make use of writing as a form to practice language. Also, most of students agreed that the teacher should underline their errors and correct errors selectively. When students were asked whether their writing had improved after the writing practice, majority of them in the direct feedback class and indirect feedback class claimed that they made progress. The results proved that teacher feedback was effective for them.

\section{Conclusion}

\subsection{Major Findings}

The purpose of this paper was to discuss whether direct feedback and indirect feedback can influence the acquisition of simple past tense in high school students' English writing in two months or so, and to find out which feedback has better effect on the acquisition of simple past tense, as well as to investigate students' preference, attitudes and expectations of teacher feedback. Two grammar tests as pretest and posttest, four writing tasks and a questionnaire have been used to make these purposes out. The major findings of this thesis can be concluded as follows:

First of all, both direct feedback and indirect feedback have an influence on the acquisition of simple past tense, which is helpful to improve students' acquisition of simple past tense. The experimental process in this study reflects the process writing theory, which emphasizes the training of language thinking ability. Feedback is a major step in process writing. The teacher gave feedback to students' writings and students corrected their writings according to the feedback. Feedback is helpful to motivate students and make students take part in the writing process actively. With the practice of narrative writing on the simple past tense, students' output on the aspect of simple past tense will be more precise and accurate.

Secondly, neither direct feedback nor indirect feedback has a greater influence on the acquisition of simple past tense in writing in this paper. According to output hypothesis theory and noticing theory, students would notice their mistakes after receiving feedback. In the direct feedback group, teachers gave the corrections directly to students. Students have noticed their mistakes, but they may not internalize them and could not grasp the essence of simple past tense. On the other hand, students in the indirect feedback group, teachers just underlined the mistakes but not corrected them. Students have noticed them but they could not correct mistakes with their limited knowledge or their limited levels. So there exists no difference between the two groups on the acquisition of simple past tense.

In this paper, the results of the pretest and posttest were used to analyze the question whether direct feedback and indirect feedback influence the acquisition of simple past tense, and the result was positive. On the other hand, the results of the four writing tasks were used to test which feedback (direct or indirect) has a greater influence on the acquisition of simple past tense in writing, but the result was negative. The pretest and posttest were made up of 20 items individually. The items are sentence error correction. However, the four writing tasks are English composition. Compared with English composition, sentence error correction is easier. As students have to think about the content, the structure, words and sentences structure, and grammar during the writing process. Writing has context, and different writings have different contexts. But students do not have to consider too much when they did the sentence error correction, that is, students were more concentrated. Context in a sentence is simpler than context in writing. Additionally, students have to consider discourse in writing. Students would make mistakes of simple past tense more easily during writing process. And this maybe one aspect which can be accounted for the result that there is no difference between the effect of direct and indirect feedback on the acquisition of simple past tense in English writing.

Lastly, when it comes to students' preferences, attitudes and expectations of teacher feedback, it can be summed up briefly as follows: Most participants in the two classes wanted their teacher to correct all their errors for them and preferred direct feedback to indirect feedback; students think teacher feedback is necessary; also they expect teacher feedback would focus more on the structure and grammar aspect; In addition, when asked whether their writing had improved after the writing practice, most of the students in the research admitted that teacher feedback is useful and helpful in the improvement of their English writings. It showed that the importance of teacher feedback was 
approved by participants.

\subsection{Pedagogical Implications}

After finishing the thesis, the author concluded several pedagogical suggestions for the teaching and learning in second language acquisition. According to the major findings, the conclusion that both direct feedback and indirect feedback are effective for improving the acquisition of simple past tense, at the same time, there exist no differences between the direct feedback and indirect feedback. Besides, students preferred direct feedback and recognized the importance of teacher feedback in improving their writing.

Firstly, when teachers meet with students' errors in revising their writing compositions, it is necessary to offer the students with feedback at a certain target structure because feedback make students notice the gaps between the output and target structure.

Secondly, when teachers plan to assign writing tasks in the learning process, they can set writing tasks which are aimed at learning a certain language structure or grammar point. As it can help students to learn and acquire the target structure more clearly and systematically, which provides students with a certain context to understand and grasp the structure. Not only can students improve writing accuracy but also consolidate the target structure.

Lastly, teachers should give feedback on the basis of students' individual conditions. Giving direct feedback or indirect feedback should depend on different situations. Hendrickson (1978) indicates that some errors should be paid more attention to correction than others, for example, those errors that hinder communication, or those that the students make more frequently. In this study, the errors of the simple past tense, which occur more frequent deserved more attention. Teachers shouldn't correct every error during the revising process, which is harmful to make students develop the habit of correcting errors by teachers. Traditionally, teacher feedback would focus on the spelling of words or the grammar mistakes; teachers also should pay attention on the structure and content. In addition, teacher feedback is not just giving grades after revising compositions, some comments especially encouraging words as well as practical and detailed suggestions can be provided, which is beneficial to improve students' self-confidence and improve their writings. As to the most widely errors in students' writings, teachers can show the errors in class as an example to explain and correct. What's more, teachers can endeavor to encourage students to practice and polish writings to make writings much better.

\section{References}

Ali J., Farahnaz R., Hsbib G., \& Akbar A. (2015). The effects of teacher-written direct vs. indirect feedback on students' writing. Procedia-Social and Behavioral Sciences, 165, 116-120. https://doi.org/10.1016/j.sbspro.2014.12.612

Bitchener, J., Young, S., \& Cameron, D. (2015). The effect of different types of corrective feedback on ESL student writing. Journal of Second Writing, 14(3), 191-205. https://doi.org/10.1016/j.jslw.2005.08.001

Carson, C. R. (1979). Feedback for Learning. In O. Miltion, (Ed.), On College Training. San Francisco CA: Jossey-Bass.

Chandler, J. (2003). The efficacy of various kinds of error feedback for improvement in the accuracy and fluency of L2 student writing. Journal of Second Language Writing, 12(3), 267-296. https://doi.org/10.1016/S1060-3743(03)00038-9

Cohen. (1987). Feedback on written composition: student and teachers verbal response. Cambridge: Cambridge University Press.

Ellis, R. A. (1997). The Study of Second Language Acquisition. New York: Oxford University Press.

Eslami E. (2014). The Effects of Direct and Indirect Corrective Feedback Techniques on EFL Students' Writing. Procedia-Social and Behavioral Sciences, 98(6), 445-452. https://doi.org/10.1016/j.sbspro.2014.03.438

Fazio, L. (2001). The effect of corrections and commentaries on the journal writing accuracy of minority- and majority-language students. Journal of Second Language Writing, 10(4), 235-249. https://doi.org/10.1016/S1060-3743(01)00042-X

Ferris, D. R. (1997). The influence of teacher commentary on student revision. TESOL Quarterly, 31(2), 315-339. https://doi.org/10.2307/3588049

Ferris, D. R. (2001). Treatment of error in second language student writing. Ann Arbor: University of Michigan 
Press.

Ferris, D. R., \& Hedgcock, J. S. (2005). Teaching ESL composition: Purpose, process, and practice (2nd ed.). Mahwah, NJ: Lawrence Erlbaum.

Ferris, D. R., \& Roberts. B. (2001). Error feedback in L2 writing class: How explicit does it need to be? Journal of Second Language writing, 10(3), 161-184. https://doi.org/10.1016/S1060-3743(01)00039-X

Frear David \& Yi-hui Chiu. (2015). The effect of focused and unfocused indirect written corrective feedback on EFL learners' accuracy in new pieces of writing. System, 53, 24-34. https://doi.org/10.1016/j.system.2015.06.006

Hattie, J. (2012). Know thy impact: Feedback for Learning. Educational Leadership, 70(1), 18-23.

Hedgcock, J., \& Lefkowitz, N. (1994). Feedback to Feedback: Assessing learner receptivity to teacher response in L2 composing. Journal of Second Language Writing, 3(2), 141-163. https://doi.org/10.1016/1060-3743(94)90012-4

Hendrickson, J. (1978). Feedback on feedback. Journal of Second Language Writing.

Keh, C, L. (1999). Feedback in the Writing Process:A Model and Methods for Implementation. ELT Journal, 44(4), 294-394. https://doi.org/10.1093/elt/44.4.294

Kepner, C. (1991). An experiment in the relationship of types of written feedback to the development of second language writing skills. The Modern Language Journal, 75(III), $305-313$. https://doi.org/10.1111/j.1540-4781.1991.tb05359.x

Kulhavy, R. W. (1977). Feedback in written instruction. Review of Educational Research, 47(11), $211-232$. https://doi.org/10.3102/00346543047002211

Lalande, J. F. (1982). Reducing Composition Errors: an Experiment. Modern Language Journal, 66(2), $140-149$. https://doi.org/10.1111/j.1540-4781.1982.tb06973.x

Leki, L. (1991). The preference of ESL students for error correction in college-level writing classes. Foreign Language Annals, 24(3), 203-2. https://doi.org/10.1111/j.1944-9720.1991.tb00464.x

Purves, A. (1984). The teacher as reader. An Anatomy College English, 46(3), $259-265$. https://doi.org/10.2307/377036

Robb, T., Ross, S., \& Shorteed, I. (1986). Salience of feedback on error and its effect on EFL writing Quality. TESOL Quarterly, 20(1), 83-93. https://doi.org/10.2307/3586390

Truscott, J. (1996). The case against grammar correction in L2 writing classes. Language Learning, 46(2), $327-369$. https://doi.org/10.1111/j.1467-1770.1996.tb01238.x

Truscott, J. (1999). The case against grammar correction in L2 writing classes. Journal of Second Language Writing, 8(2), 1-10. https://doi.org/10.1016/S1060-3743(99)80124-6

Ur, P. (1996). A Course in Language Teaching: Practice and Theory. Cambridge: Cambridge University Press.

Wiggins, G. (2012). Seven keys to effective feedback. Educational Leadership: Feedback for Learning, 70(1), 10-16.

Xuemei Zhang \& Weidong Dai. (2001). Feedback in second language acquisition language teaching. Foreign Language World, 2, 2-8. 